\title{
7. Follow-up: strict adherence or divergence?
}

\section{INTRODUCTION}

The previous two chapters revealed that some judges - especially Dutch and UK judges - are critical of their interaction with the ECJ. The judges interviewed pointed to the gap between the rhetoric of a horizontal dialogue and the reality of a vertical monologue. Judges also lamented the 'ivory tower' or 'oracle' mentality of the ECJ, and their exclusion from the preliminary reference process after a referral has been submitted. Although judges were satisfied with the vast majority of the requested answers, they were critical about specific judgments. In light of this feedback, one might expect that national courts do not always follow up on ECJ judgments. However, this chapter will reveal the somewhat surprising conclusion that the national courts almost always implement the ECJ's answer in full. This conclusion is perhaps less surprising if one considers the logic of a UK High Court judge: 'National courts do not make references to the ECJ with the intention of ignoring the result.'

This chapter will show that there is a difference between the three countries studied in terms of the extent to which the referring court ends the procedure with a written follow-up judgment (section 2). This notwithstanding, national courts and judges adhere strictly to the binding nature of ECJ judgments and implement the rulings automatically and in full (section 3). One exception to this situation is where additional follow-up questions are issued, with the aim of indicating the referring court's dissatisfaction with the ECJ judgment (section 4). However, most follow-up references are aimed not at avoiding compliance, but rather at raising points that either were not put before the ECJ in the initial reference or were evaded by the ECJ itself.

Case C-206/01 Arsenal EU:C:2002:651; Arsenal Football Club plc v Reed [2002] EWHC 2695 (Ch) (Laddie J), paras 27-29. 


\section{NO (WRITTEN) FOLLOW-UP JUDGMENT IN ECJ OUTCOME JUDGMENTS}

There is some divergence in how national courts follow up on ECJ judgments. While relatively few written follow-up judgments were found in the UK and Ireland, written follow-up judgments are almost the rule in the Netherlands. In the UK and Ireland, the parties normally reach agreement after the ECJ judgment and submit an agreed order for the court to sign. Referring courts often close the case through an oral order that is not published; or sometimes through a very short, one-page follow-up judgment which merely mentions that 'it is common ground between the parties...'. ${ }^{2}$ The practice of the UK courts is a good illustration of this: only one written Court of Appeal judgment was found following 18 ECJ judgments issued since 2013; and a written UK Supreme Court judgment disposing of the case was made in only three of the 12 cases referred to the ECJ since 2013. The most recent was Vomero, which was discussed in the previous chapter as a relatively problematic ECJ judgment (Chapter 6, section 2.1). ${ }^{3}$ A further hearing and written judgment are considered necessary only if the parties are unable to agree. ${ }^{4}$ This happened in Teva, where both parties argued that they had won on the basis of the ECJ judgment. ${ }^{5}$ The previously discussed case of Newby also led to further litigation before the High Court, the Court of Appeal and the Supreme Court, because of problematic aspects in the answer of the ECJ (Chapter 6, section 3.2). The same can be said of the extensive follow-up judgment of 1000 paragraphs in British American Tobacco. ${ }^{6}$

These figures confirm that ECJ judgments often dispose of the case because of the highly specified nature of the ECJ's answers. This happens, for example, where the ECJ finds that EU law is not invalid. ${ }^{7}$ In $M B$, for example, the ECJ held unequivocally that the UK law constituted direct discrimination on the

2 Shields and Sons Partnership v HMRC [2017] UKUT 504 (TCC). The Irish Supreme Court explicitly noted in its follow-up judgment that it is not necessary 'to repeat the clarification provided by the decision of the ECJ', Nawaz v Minister for Justice [2014] IESC 30 (O'Donnell J), para 14; Interviews 121, 133, 136, 152, 166, 174, 188, 231 and 276.

3 De Búrca found follow-up judgments in 26 of the 113 UK cases referred between 2008 and 2018. De Búrca 2020; SSHDs v Franco Vomero (Italy) [2019] UKSC 35.

4 Trustees of The P Panayi Accumulation and Maintenance Trusts Nos 1-4 v HMRC [2019] UKFTT 622 (TC), para 1. Cf Arnold 2020.

5 Teva UK Ltd \& Ors v Gilead Sciences, Inc [2019] EWCA Civ 2272, para 6.

6 British American Tobacco (UK) Ltd \& Ors, $R$ (On the application of) $v$ The Secretary of State for Health [2016] EWHC 1169 (Admin).

7 Eg Case C-134/13 Raytek and Fluke Europe EU:C:2015:82. 
grounds of sex and was prohibited. ${ }^{8}$ Another example is the outcome judgment of the ECJ in The English Bridge Union, in which the ECJ determined that duplicate bridge is not a 'sport' in the sense of the VAT Directive because of the limited physical elements involved. ${ }^{9}$ Faced with such unequivocal outcome judgments, it often happens that one of the parties withdraws the case after the ECJ judgment or a settlement is reached. One UK judge noted, on the basis of this practice, that apparently most ECJ judgments are sufficiently clear. ${ }^{10}$

The practice in the Netherlands is different: the answers of the ECJ are almost always followed up with a written follow-up judgment from the referring court. The 13 references of the Civil Chamber of the Supreme Court are a good illustration of this: a written follow-up judgment was issued in ten of the 12 references that resulted in a ECJ judgment. In most of these cases, the follow-up judgment was even preceded by an AG Opinion - often the second opinion in the case. ${ }^{11}$ The court even referred five cases back to the court of appeal to decide on points of fact. ${ }^{12}$ One exception is the earlier discussed outcome judgment in GS Media, about a hyperlink to a website that contained leaked nude photographs (Chapter 6, section 3.2). The ECJ judgment disposed of the case and made further litigation unnecessary, since it was clear which party was successful. ${ }^{13}$

The contrast between the Irish and UK practice on the one hand, and the Dutch situation on the other, can partly be attributed to the types of questions asked. As the previous discussion suggests, outcome judgments often require less from the referring court in terms of follow-up. Both the Irish and UK courts have primarily referred clearly delimited questions, resulting in concrete outcome judgments that generate limited discussion. ${ }^{14}$

\section{BINDING ECJ JUDGMENTS AND AUTOMATIC FOLLOW-UP}

There is a significant - and unsurprising, from an EU law point of view - consensus among courts in the three countries that ECJ judgments are binding.

Case C-451/16 MB EU:C:2018:492.

Case C-90/16 The English Bridge Union EU:C:2017:814.

Interview 231.

11 Eg Case C-610/15 Stichting Brein EU:C:2017:456; Stichting Brein v Ziggo and XS4ALL NL:PHR:2018:202; Stichting Brein v Ziggo and XS4ALL NL:HR:2018:1046.

12 Commerz NL:HR:2016:994; Hauck NL:HR:2015:3394; Ryanair NL:HR:2016: 390; Stichting Brein v Ziggo and XS4ALL NL:HR:2018:1046; Diageo Brands NL:HR: 2016:1431.

13 Case C-160/15 GS Media EU:C:2016:644, para 54; Interviews 27, 45 and 87. Cf C-419/13 Art and Allposters International EU:C:2015:27.

14 Interviews 148, 152, 153, 155, 181 and 231. 
Courts have reaffirmed the binding nature of ECJ judgments in their decisions and the judges interviewed cast no doubt on this absolute obligation. ${ }^{15}$ Dutch Supreme Court judges observed that ECJ judgments simply constitute law and cannot be disputed. ${ }^{16}$ One judge even stated that what the ECJ says is true and compared it - somewhat jokingly - to a papal bull; while another suggested that the Supreme Court's conscientious approach involves simply adhering to ECJ judgments without a second thought. ${ }^{17}$

Courts have upheld this strict obligation even in several of the problematic cases that were previously discussed. For example, in Patmalniece, Lord Walker noted that the UK Supreme Court must follow the ECJ, 'even if some of us do not fully understand its reasoning'. ${ }^{18}$ The UK Supreme Court likewise stated in its written response to an interview question: 'regardless of the clarity or otherwise of the reasoning of a decision, the Supreme Court will do its best to follow and apply the decision. ${ }^{19}$ An older illustration is the House of Lords' compliance with the ECJ's landmark judgment in Factortame by suspending the application of the Merchant Shipping Act 1988 and holding the UK government liable, despite criticisms regarding the ECJ's factual interference and notwithstanding the significant financial consequences for the government. ${ }^{20}$ Hogan - who was involved in the earlier discussed problematic cases of $M M$ and Danqua - stated:

I do not see how this Court can in any way look behind the judgment of the Court of Justice, even if some might regard the fact that the Court went beyond the scope of the questions posed in the original Article 267 reference by addressing an entirely new question as unsatisfactory. ${ }^{21}$

Meanwhile, one Irish judge observed: 'If Irish law turns out to be deficient, so be it. If the ECJ arrives at a different interpretation, so be it. ${ }^{22}$

The legal (and perceived) binding nature of ECJ judgments thus translates into almost complete follow-up. In the analysis of national courts' follow-up judgments in light of the requested ECJ judgment, no case was found in which a referring court departed from or ruled contrary to the interpretation of the

\footnotetext{
15 Interviews 15, 27, 34, 41, 146, 159 and 162; Clarke 2019; SSHD v Davis MP \& Ors [2015] EWCA Civ 1185, para 102.

16 Interviews 15, 30, 34, 41 and 78.

17 Interviews 78 and 27 respectively.

18 Patmalniece v SSWP [2011] UKSC 11 (Lord Walker), para 73. Cf UK courts in relation to the ECJ's private international law case law. Harris 2008, 349.

19 Written response 15 April 2020.

20 Arnull 2010, 67.

21 [2017] IECA 20, para 36. Cf Interview 166.

22 Interview 159.
} 
ECJ. ${ }^{23}$ Most of the examined follow-up judgments failed to mention any of the dissatisfactions outlined in the previous chapter, ${ }^{24}$ or did so only in rather implicit terms. One Irish example is the child protection case $J D,{ }^{25}$ in which one Supreme Court judge 'respectfully disagreed' with the ECJ on some issues. The Supreme Court 'made a grumpy judgment afterwards', albeit that it did not deviate from the ECJ's interpretation. ${ }^{26}$

In light of the previous account, it is unsurprising that most of the judges interviewed approached follow-up as an automatic exercise, even in cases that demanded a shift in their own position. ${ }^{27}$ They accepted that such full compliance is 'just the way it is' or 'part of the game'. ${ }^{28}$ Legal certainty, including with regard to the execution of ECJ judgments, is considered more important than judges' own ideas about the state of the law. ${ }^{29}$ As previously discussed, this pragmatic approach to follow-up can also be attributed to the fact that judges usually have no clear preferences or agendas, and seldom care about the outcome of a particular case. ${ }^{30}$ A difference of opinion 'does not matter' and the national courts will thus comply with the ECJ judgment notwithstanding. ${ }^{31}$ Judges found it more annoying when no (clear) answer was provided by the ECJ than when the ECJ took a different, but well-reasoned approach from the referring court. ${ }^{32}$ Dutch tax law judges had no 'hard feelings' and did not feel repudiated when the ECJ diverged from the preferred answer of the referring court, as in Kieback: 'That is just the way it is. ${ }^{33}$ With respect to the previously discussed inconsistencies in the Schumacker tax cases, Dutch judges

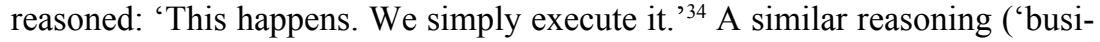
ness as usual') was applied to the Amersfoort fees case $(X)$, in which there was a suspicion that the ECJ had misunderstood the Supreme Court. ${ }^{35}$ Even in Diageo Brands, on the execution of a Bulgarian judgment that was (allegedly) in breach of EU law, the Supreme Court held that despite its considerable

\footnotetext{
23 Interviews 27 and 166. Cf about the UK, de Búrca 2020.

24 Eg Sopora NL:HR:2016:360.

25 Case C-428/15 JD EU:C:2016:819.

26 The Supreme Court judgment also notes that 'these conclusions were at variance from those I expressed' in the order for reference. [2017] IESC 56 (Charleton J); interview 128.

27 Cf Schwarze 1988.

28 Interviews 5, 15, 18, 34, 72, 77, 82, 89 and 91; Sevenster and Wissels 2016, 93.

29 Interviews 15 and 34.

30 Interviews 15,34 and 82 .

31 Interview 133. Cf Interview 121 and 188.

32 Interviews $12,18,72$ and 91.

33 Case C-9/14 Kieback EU:C:2015:406; Interviews 33 and 82.

34 Case C-279/93 Schumacker EU:C:1995:31; Interview 78.

35 Interview 15.
} 
frustration, it could not examine the correctness of the ECJ judgment. ${ }^{36}$ The Central Appeals Tribunal even 'defended' the ECJ in Franzen, in which the latter had incorrectly interpreted the Dutch law. ${ }^{37}$ The Council of State likewise complied without demur with the ECJ's requirement in $Z h$ and $O$ that an individual assessment be conducted of the risk posed to public security or national security by third-country nationals and EU citizens alike, contrary to what the Council of State had initially thought. ${ }^{38}$ The council also changed its approach after $J N$, which confirmed that its more fundamental-rights-friendly approach deviated from the requirement under the Reception Conditions Directive that removals be carried out as soon as possible. ${ }^{39}$ Another Irish example is the previously discussed 'lost in translation' case of $M M$, which concerned the right to a hearing. Despite the problems discussed in Chapter 6, section 3.1, Hogan's follow-up decision was fully in line with the ECJ judgment and he noted that he 'must naturally apply the judgment' ${ }^{40}$ However, this faithful application was subsequently criticized by other judges, as the introduction of personal interviews for subsidiary protection and a broadened scope of appeal rights caused gridlock in the system. ${ }^{41}$ One interviewee, for example, noted that Hogan had reasoned along the lines: 'I cannot really say that the ECJ has failed to understand. There must be something wrong with the Irish procedure. I have to condemn the procedure, even though I am not quite sure how.' Hogan thus made an 'informed guess' as to what the ECJ might have meant, on the basis that the ECJ was 'evidently troubled' in making its decision. ${ }^{42}$

National judges are thus pragmatic not only regarding the decision to refer, but also in relation to follow-up and compliance. What is important to them is whether the ECJ judgment helps them to resolve the case at hand ${ }^{43}$ Hence, even problematic judgments can ultimately be adequate or useful, despite frustrations over the deficient reasoning of the ECJ or the incorrect reformulation of the question. One example of such a judgment is Essent. In this case, the Council of State asked a question on the EEC-Turkey Association Agreement

\footnotetext{
36 Case C-681/13 Diageo Brands EU:C:2015:471; Diego Brands NL:HR:2016: 1431, para 4.2.1.

37 Case C-382/13 Franzen EU:C:2015:261; Franzen NL:CRVB:2016:2144, para 4.13

38 Case C-554/13 Zh and $O$ EU:C:2015:377; Interviews 10 and 89; NL:RVS:2015: 3579 , para 7.

39 Case C-601/15 PPU JN EU:C:2016:84, paras 75-76; NL:RVS:2016:959, para 3.2 .

40 MR \& Anor v An t-Ard Claraitheoir \& Ors [2013] IEHC 91 (Hogan J), para 50; Interview 144 and 181.

41 Interviews 113, 144, 171 and 181.

42 Interview 144.

43 Micklitz 2005, 433; Interviews 10, 18 and 91.
} 
(1/80), but the ECJ did not consider this agreement and instead focused on the free movement rules set out in the TFEU. One judge considered this frustrating, but another made clear that the ECJ judgment was nonetheless useful: it disposed of the case and resulted in a relatively short follow-up judgment. ${ }^{44}$

In some cases, such as Newby (Chapter 6, section 3.2), the UK lower courts initially decided not to follow the ECJ, but were subsequently corrected by a higher court. This also happened in the famous Arsenal case, which concerned the sale of scarves marked in large lettering with the word 'Arsenal' - a sign which is registered as a trademark by Arsenal Football Club. ${ }^{45}$ The referring High Court judge, Justice Laddie, took offence with the alleged finding of fact by the ECJ. He held that the ECJ had exceeded its jurisdiction in disagreeing with the High Court's earlier findings of fact that the use of the 'Arsenal' sign by Mr Reed did not indicate trade origin. The High Court did not consider itself bound by this and applied the ECJ's interpretation of EU law to its own factual findings, as a result of which the defendant, Mr Reed, prevailed. ${ }^{46}$ The Court of Appeal quashed this decision and held that the ECJ judgment should have been followed and decided in Arsenal's favour. The court found that the ECJ had not disregarded the High Court's conclusions of fact and held that the outcome was inevitable in light of the interpretation of the ECJ. ${ }^{47}$ Fifteen years later, the Upper Tribunal corrected the First-Tier Tribunal in a customs classification case. The First-Tier Tribunal had determined that the ECJ's classification was 'guidance only and not binding', as it was based on a factual conclusion with which the tribunal disagreed, given the evidence before it. ${ }^{48}$ The Upper Tribunal overturned this decision and found that the First-Tier Tribunal had applied the ECJ judgment incorrectly. ${ }^{49}$

There are two exceptions to this full compliance record. First, courts have maintained the effects of ECJ judgments. ${ }^{50}$ Second, Dutch and UK courts have found a way around the difficulties presented by factual determinations of the ECJ by concluding that they are not bound by an ECJ ruling on the facts. With regard to this latter exception, the Dutch Supreme Court stipulated that Dutch procedural law did not allow it to take into consideration the facts as determined by the ECJ in Ten Kate Holding Musselkanaal. ${ }^{51}$ One interviewee declared

\footnotetext{
Case C-91/13 Essent EU:C:2014:2206; NL:RVS:2014:4028; Interview 89. C-206/01 Arsenal EU:C:2002:651, para 61.

46 Arsenal Football Club plc v Reed [2002] EWHC 2695 (Ch) (Laddie J), paras

47 Arsenal Football Club plc v Reed [2003] EWCA Civ 696.

Invamed Group Ltd \& Ors v HMRC [2016] UKFTT 775 (TC), para 47.

HMRC v Invamed Group Ltd \& Ors [2018] UKUT 305 (TCC).

Conant 2002.

${ }^{51}$ Staat v Ten Kate Holding Musselkanaal NL:HR:2006:AZ3083, para 2.2.2.
} 27-29. 
himself/herself flabbergasted by this judgment, in which the ECJ had relied on the intervention of the Commission and the Dutch government, and which had come as a complete surprise. ${ }^{52}$ In the previously discussed case of Aimia, Lord Hope emphasized that it is the responsibility of the UK Supreme Court to apply the principles to the facts of the case. ${ }^{53}$ One interviewee revealed that the UK Supreme Court was divided on the question of compliance. Two judges contended that Luxembourg had spoken and that the UK Supreme Court had to apply its judgment; while three judges did not entirely agree with this. The UK Supreme Court ultimately 'struggled through' and made no second follow-up reference. ${ }^{54}$ It took account of factual elements and arguments that were not reflected in the ECJ judgment. ${ }^{55}$ Previously, the House of Lords deviated from 'the duty of this House to give effect to the law as declared in Luxembourg' in North Wales Training and Enterprise Council, which concerned a transfer of undertakings. One interviewee noted that this was a 'very unsatisfactory' ECJ judgment, with rather factual answers regarding the date of effective transfer. The House of Lords thus 'happily disagreed' and refused to follow it. ${ }^{56}$ It stuck to the facts as 'long accepted', because 'the facts cannot be changed because an unforeseen legal argument makes them damaging to' the applicants. ${ }^{57}$

The referring courts have also 'contained' the effects of ECJ judgments while avoiding clear situations of non-compliance - either by not awarding the full amount of claimed damages or even by awarding no damages at all. ${ }^{58} \mathrm{In}$ a few cases, the referring court reinterpreted the facts so that the ECJ judgment did not apply. ${ }^{59}$ One UK example is The Scotch Whisky Association, which concerned minimum pricing of alcohol in light of the free movement of goods. The UK Supreme Court followed the Court of Appeal and allegedly considered it inappropriate to overturn a flagship policy of the government. It did not as such overturn the general principles set out by the ECJ, but availed of the degree of deference left to it in the ECJ judgment. By applying the proportionality analysis differently, the Supreme Court avoided finding a breach of

\footnotetext{
Case C-511/03 Ten Kate Holding Musselkanaal EU:C:2005:625.

HMRC v Aimia Coalition Loyalty UK Ltd [2013] UKSC 15, para 103.

Interview 208.

Reed 2014, 13-14.

Interview 264.

57 North Wales Training and Enterprise Council Ltd $v$ Astley \& Ors. [2006] UKHL

${ }_{58}$ Eg the follow-up judgment in Case C-6/90 Francovich EU:C:1991:428 as discussed by Pollack 2017, 592.

59 One old example is Case C-131/79 Regina EU:C:1980:131. The UK High Court held that 'guidance is expressed in general terms and it is our duty to apply it to the facts of the case', Nyikos 2003, 399.
} 29 , paras 8 and 9 . 
EU law. ${ }^{60}$ Together with North Wales Training and Aimia, this case illustrates that the UK Supreme Court has followed the example of other apex courts and has become increasingly assertive in limiting the effects to be given to ECJ judgments due to a certain feeling of discontent. ${ }^{61}$ Another famous instance of a more subtle 'containment' is Melloni. The Spanish Constitutional Court did not really engage with the answers of the ECJ in its follow-up judgment and seemed to suggest that it reached its conclusions by itself. ${ }^{62}$ In other cases, the referring courts have ignored the vague standards and limited operational guidance contained in the ECJ judgment by adopting a seemingly different interpretation. ${ }^{63}$

One interesting Swedish case sheds further light on the growing assertiveness of some national courts, including the UK Supreme Court. The Swedish Supreme Court did not comply with the ECJ's judgment in Billerud, which focused on greenhouse gas emissions trading and fines. It held that a national court may disregard the ECJ's interpretation of EU law if it constitutes a serious and unequivocal breach of the European Convention on Human Rights (ECHR). ${ }^{64}$ The court's non-compliance was attributed to Sweden's strong national environmental law tradition, which is distinct from mainstream EU environmental law. Sweden has a specialized court that deals with environmental matters, with technical judges who are not lawyers, but ecologists. This suggests that specialization is not a factor that exclusively favours (positive) engagement with EU law; it can also be a negative factor. The more specialized the court, the greater its ability to spot deficiencies in its interaction with a supranational court that allegedly lacks such technical and specialized knowledge. ${ }^{65}$ UK Supreme Court judges have likewise been critical of the private law expertise of the ECJ (Chapter 2, section 3.2). It is thus unsurprising that such ideas can affect the courts' eagerness to comply with ECJ judgments.

In sum, aside from a handful of exceptions, national courts have almost always complied with the requested ECJ rulings. This corroborates the findings from earlier studies, including Nyikos' conclusion in 2003 that there is 'a habit of obedience' ${ }^{66}$ Several studies on environmental law similarly found that ECJ judgments were all adhered to by referring courts in Belgium, the

60 Case C-333/14 The Scotch Whisky Association EU:C:2015:845; Scotch Whisky Association \& Ors $v$ The Lord Advocate \& Anor (Scotland) [2017] UKSC 76, para 63; Interview 211, 231; Dunne 2018.

61 Arnull 2017, 315; Harris 2009, 383; Interviews 211 and 231.

62 Case C-399/11 Melloni EU:C:2013:107; Pérez 2014, 322-23.

63 Eliantonio and Favilli 2020.

64 Case C-203/12 Billerud EU:C:2013:664; Bogojevíc 2017, 274-76.

65 Squintani and Kalisvaart 2020.

66 Nyikos 2003, 398; Mestmäcker 1994, 623. 
Netherlands and the UK. ${ }^{67}$ The practice in the three countries studied stands in sharp contrast to a handful of pronouncements of courts in other EU Member States - most notably, the recent declaration of an ECJ judgment as ultra vires by the German Constitutional Court in Weiss. Other well-known instances of national court rebellions include Dansk Industri and Landtová. The Danish Supreme Court refused to comply with the ECJ judgment and held that an unwritten general principle of EU law prohibiting age discrimination could not set aside Danish law in a horizontal dispute. ${ }^{68}$ The Czech Constitutional Court declared the ECJ judgment ultra vires because the ECJ had wrongly applied EU Regulation 1408/71 on the coordination of social security schemes to a situation that lacked cross-border elements. ${ }^{69}$

\section{FOLLOW-UP REFERENCES}

As the previous section has shown, the national court almost always adheres to the requested ruling of the ECJ. One exception is where additional follow-up questions are submitted to the ECJ. ${ }^{70}$ However, most of these follow-up references have different objectives from merely avoiding compliance or challenging the ECJ - the aim instead is to submit new questions that were not put to the ECJ in the initial reference or to address points that the ECJ itself avoided. This section will discuss such follow-up questions. Before doing so, however, it is important to emphasize that national courts are generally reluctant to make additional references. They are pragmatic and try to 'struggle' through with the ECJ judgment. If the ECJ judgment does not give a (satisfactory) answer on all points, there is a tendency not to 'push through' on specific points. ${ }^{71}$ Lord Reed noted that the approach of the UK Supreme Court is to apply the ECJ's interpretation rather than to make additional references. Even where the ECJ has come up with an ambiguous principle of interpretation, the prevailing feeling is that another reference would 'add little or nothing' ${ }^{72}$ In several cases the AG recommended that the Dutch Supreme Court submit follow-up references, but to no avail. ${ }^{73}$ One judge interviewed referred to cases in which

\footnotetext{
67 Squintani and Kalisvaart 2020; Arnull 2010, 81.

68 Case C-441/14 Dansk Industri EU:C:2016:278. Previously, the Danish Supreme Court held in its judgment on the constitutionality of the Lisbon Treaty that interpretation of EU law of the ECJ 'must not result in a widening of the scope of Union powers'. Lisbon Danish Supreme Court Case 199/2012; Krunke 2014; Šadl and Mair 2017, 359.

69 Case C-399/09 Landtová EU:C:2011:415.

70 Dani 2017b, 799.

71 Interview 18.

72 Reed 2014, 6.

73 Interviews 30 and 33. Eg A-G Verkade in NL:PHR:2013:114, para 4.15; Case C-324/08 Makro EU:C:2009:633.
} 
the AG suggested that the ECJ's decision was 'nonsense', but the Supreme Court was reluctant to follow the AG's position given its sense of loyalty to the court ('It is Luxembourg that has spoken'). ${ }^{74}$ One Irish judge also noted that if a follow-up question is necessary, it should ideally be made by a higher court. ${ }^{75}$ Although he was tempted to do so, High Court judge Arnold also decided against making a follow-up reference in the Nestlé case - a trademark dispute over Kit-Kat's four-finger chocolate bar. He did not expect that another reference would lead to a different outcome. He consequently tried to understand and apply the ECJ's answer as best as he could. ${ }^{76}$ Likewise, the UK Supreme Court considered it unnecessary to make a further reference in relation to the much-contested ECJ judgment in Aimia, because the relevant principles were known and the case could be decided in light of the guidance given. ${ }^{77}$ This reasoning was also applied by other UK courts, with reference to the ECJ case law. The UK Court of Appeal, for example, observed that the ECJ has discouraged courts from making a second reference in relation to a legal issue or provision considered in the initial reference. ${ }^{78}$ The Court of Appeal dismissed the need to make a second reference following the ECJ decision in $N A$ because there was 'sufficient guidance on the correct approach'. ${ }^{79}$

The first category of follow-up questions comprises those made by higher courts on points that were not put before the ECJ in the initial reference. Several of these follow-up references resulted from a deficient initial reference, often due to a lower court providing insufficient clarity on, for example, the national legal framework. The most prominent Irish example is the $M M$ saga on subsidiary protection, discussed in Chapter 6, section 3.1. The ECJ went beyond the scope of the questions submitted by the High Court and made some factual pronouncements on the (right to a) hearing. This was attributed to the limited information provided in the order for reference about the subsidiary protection procedure and the scope of the hearings. ${ }^{80}$ Hence, a second referral by the Supreme Court was needed to compensate for these omissions and clarify the concept of a 'hearing'. The Irish case of Farrell - on direct effect,

\footnotetext{
74 Interview 30.

75 Interview 139.

76 Société Des Produits Nestlé SA v Cadbury UK Ltd [2014] EWHC 16 (Ch), paras 45 and 48.

77 Reed 2014, 13-14.

78 British American Tobacco UK Ltd \& Ors, $R$ (on the application of) $v$ The Secretary of State for Health [2016] EWCA Civ 1182. Cf Case C-338/95 Wiener EU: C:1997:352.

79 Baigazieva v SSHD [2018] EWCA Civ 1088. Cf British American Tobacco UK Ltd \& Ors, R (on the application of) $v$ The Secretary of State for Health [2016] EWCA Civ 1182.

80 Interviews 144, 152 and 159.
} 
the concept of an emanation of the state and the possibility to rely on EU law provisions against a private law body - was referred twice due to the 'fault' of the High Court, which had (probably) not referred all necessary questions. ${ }^{81}$ The Dutch Supreme Court gave a sub-district court (kantonrechter) a rap on the knuckles in relation to the reference it submitted in Smallsteps about the safeguarding of employees' rights in a transfer of undertakings via a 'pre-pack' that is prepared before the declaration of insolvency and put into effect immediately after the declaration. The initial reference was made by a single judge who had never made a reference before. ${ }^{82}$ Three years after the ECJ judgment, the Supreme Court decided to refer additional questions because it felt that the sub-district court had not provided sufficient details about Dutch insolvency law and the purpose and organization of the pre-pack, and the ECJ was thus unable to consider those aspects in its judgment. ${ }^{83}$

The UK Court of Appeal also made a second reference - with some regret - in the copyright case of ITV Broadcasting, which concerned the notion of 'communication to the public'. This was necessary because the issues on which the appeal turned were never fully developed before the High Court. ${ }^{84}$ The VAT case of Marks and Spencer was referred again by the House of Lords because the initial reference of the Court of Appeal was 'not sharp enough' ${ }^{85}$ This case concerned the repayment of VAT that had been wrongly paid in respect of the sale of gift vouchers, and its relationship to the principles of effectiveness and the protection of legitimate expectations. The second reference resolved the case and confirmed that sometimes a 'second shot is helpful'. There was no feeling of unease at the House of Lords or the ECJ, because everyone understood that this was a difficult case. ${ }^{86}$ Another UK example is Test Claimants - a protracted litigation that resulted in three references to the ECJ. This very complex and technical case is still before the UK Supreme Court after an initial reference was made by the High Court back in 2004. It concerns tax paid by UK resident parent companies on dividends received from their foreign subsidiaries, and an alleged difference of treatment between UK resident and non-UK resident companies. The case involves intricate issues of

${ }^{81}$ Farrell was referred twice, once by the High Court in Case C-356/05 (Farrell EU:C:2007:229) and ten years later by the Supreme Court in Case C-413/15 (Farrell EU:C:2017:745); Interview 152.

$82 \quad F N V v$ Smallsteps NL:RBMNE:2016:954.

83 FNV v Heiploeg-concern NL:HR:2020:954, para -3.11.3.

84 Case C-607/11 ITV Broadcasting EU:C:2013:147; ITV Broadcasting Ltd \& Ors $v$ TVCatchup Ltd \& Ors [2015] EWCA Civ 204, para 89.

85 Case C-62/00 Marks and Spencer EU:C:2002:435; Case C-309/06 Marks and Spencer EU:C:2008:211.

86 Interview 208. 
restitution and damages; points that were left to the referring court regarding liability and limitation periods by the ECJ required further references. ${ }^{87}$ Both Test Claimants and Marks and Spencer suggest that additional references are sometimes unavoidable due to the complexity of the proceedings and the legal framework.

A second category of follow-up questions comprises those that are due to an omission of the ECJ in its judgment, rather than an omission of the national court in its order for reference. A follow-up reference is sometimes necessary to address the lack of clarity in the initial ECJ judgment. ${ }^{88}$ This can happen in particular with rather deferential ECJ judgments that leave considerable room to the referring court, which can also lead to additional questions. One example is $O^{\prime} B y r n e v$ Aventis, a product liability case concerning brain damage caused by a vaccine. The ECJ left it to the national court to determine the conditions under which one party may be substituted for another in an action brought against a company that was mistakenly considered to be the producer, whereas in fact the product had been manufactured by another company. The referring High Court had to ensure that due regard was paid to the personal scope of the Product Liability Directive (85/374). In the second reference, the House of Lords asked the ECJ about the ten-year limitation period and the consistency of the UK procedural rules with EU law. ${ }^{89}$ The UK Supreme Court concluded in its follow-up judgment that: 'Happily ... this time the core answer could not be clearer. ${ }^{90}$ The Dutch Central Appeals Tribunal considered making a second reference after the ECJ judgment in Akdas, which concerned the portability of social security allowances for migrant workers from Turkey, because the ruling was unclear in several respects. ${ }^{91}$ Instead, these question were raised in a later case (Demirci), in which - unlike in Akdas - the Turkish workers had acquired Dutch nationality.

Follow-up references can also be necessary if the ECJ has dodged the initial questions. One Dutch example is the previously discussed Council of State reference in Visser Vastgoed, which was made after the ECJ had failed to address the applicability of the Services Directive in purely internal situations

87 Arnull 2017, 328-31; Case C-446/04 Test Claimants in the FII Group Litigation EU:C:2006:774; Case C-35/11 Test Claimants in the FII Group Litigation EU:C:2012: 707; C-362/12 Test Claimants in the FII Group Litigation EU:C:2013:834; For a good overview, see Test Claimants in the Franked Investment Income Group Litigation $v$ HMRC [2016] EWCA Civ 1180, paras 7-21.

88 Arnull 2017, 331; Jacobs et al 2019, 1218.

89 Case C-127/04 O'Byrne EU:C:2006:93; Case C-358/08 Aventis Pasteur EU:C: 2009:744.

90 OB (by his mother and litigation friend) (FC) v Aventis Pasteur SA [2010] UKSC 23, para 10 .

${ }_{91}$ Case C-485/07 Akdas EU:C:2011:346; Case C-171/13 Demirci EU:C:2015:8. 
in Trijber and Harmsen. ${ }^{92}$ Another UK High Court judge, Justice Arnold, simply repeated the question he had initially raised in Actavis $v$ Sanofi on the criteria for deciding whether a product is protected by a basic patent in force in the sense of the SPC Regulation. In the order for reference, he expressed his 'hope that finally a clear answer will be given' and that 'further and better guidance' would be provided. ${ }^{93}$

A third category of additional follow-up references is those that aim to express the referring court's dissatisfaction and substantively challenge the ECJ judgment. Through these references, the referring court is basically asking the ECJ whether it is really sure about its initial ruling. Nyikos has described such follow-up references as 'evasion' or 'non-implementation' ${ }^{94}$ One prominent Italian example is the second reference of the Italian Constitutional Court following Taricco, in which the ECJ prioritized tackling VAT fraud over the principle of legality. ${ }^{95}$ The Irish and Dutch courts are generally reluctant to make this type of reference. ${ }^{96}$ One of the few Dutch exceptions is the Council of State's second reference on the recovery of wrongfully granted subsidies in Somvao, as its discontent with the earlier ESF ruling resulted in tension with the principle of the protection of legitimate expectations. ${ }^{97}$

More of these follow-up references have been made in the UK. UK judges seem to find it less problematic to make a second reference in order to express their disagreement. ${ }^{98}$ One pertinent example is Kaba, which was referred twice by the immigration adjudicator two decades ago. In its second reference, the adjudicator cast doubt on the factual basis of the ECJ's ruling. The party to the case, Mr Kaba, had informed the ECJ of his doubts as to the accuracy of the factual basis of the AG's Opinion, not least because of the submissions of the UK government; and had unsuccessfully requested that the oral procedure be reopened. The main substantive point of contention was that the ECJ had incorrectly treated the status of third-country nationals with indefinite leave to remain in the UK as being significantly more secure than the status of EU nationals in the UK. The adjudicator asked the ECJ whether its initial reply in Kaba would have been different had the ECJ taken

\footnotetext{
Joined Cases C-360/15 and C-31/16 X and Visser Vastgoed EU:C:2018:44.

93 Teva UK Ltd \& Ors v Gilead Sciences Inc [2017] EWHC 13 (Pat), paras 91 and 95.

94 Nyikos 2003, 399; Jacobs et al 2019, 1219.

95 Case C-105/14 Taricco EU:C:2015:555; Case C-42/17 MAS and MB EU:C: 2017:936; Garner 2017; Repetto 2015; Timmerman 2016; Bassini and Pollicino 2017; Billis 2016; Giuffrida 2016.

96 Interviews 27 and 45. Cf A-G Hammerstein in NL:PHR:2014:1736, para 2.5.

97 Case C-383/06 ESF EU:C:2008:165; Case C-599/13 Somvao EU:C:2014:2462.

98 Interview 208.
} 
account of the correct facts, and whether the procedure followed by the ECJ in response to the first reference complied with Article 6 ECHR. ${ }^{99}$ Another classic example is the Sunday trading saga, on UK legislation that prohibited retailers from opening their premises on Sundays. In Council of the City of Stoke-on-Trent, the House of Lords asked the ECJ for further guidance following its rather deferential answers in Torfaen Borough Council. ${ }^{100}$ The ECJ had initially determined that the current Article 34 TFEU on the free movement of goods did not apply to Sunday trading rules where the restrictive effects on trade did not exceed the effects intrinsic to the free movement rules. ${ }^{101}$ In its answer to the House of Lords, the ECJ unequivocally made clear that Article 34 TFEU did not apply to the rules. Another UK example is Privacy International, in which the Investigatory Powers Tribunal challenged Digital Rights Ireland, which had been referred by an Irish court. It questioned whether the ECJ had truly intended to provide compulsory requirements and suggested that the ECJ's interpretation went beyond the scope of EU law because it was only 'incidentally relevant' to the retention regime. The tribunal also doubted whether the ECJ intended to go beyond the case law of the ECtHR. ${ }^{102}$ This second reference was ultimately to no avail, as the Grand Chamber of the ECJ confirmed that state authorities cannot require electronic communications providers to transmit traffic and location data to security and intelligence agencies for the purpose of safeguarding national security. ${ }^{103}$

\section{CONCLUSION}

This chapter has shown that the courts in the three countries studied generally comply diligently - and almost automatically - with ECJ rulings, even in the problematic and dissatisfactory cases discussed in Chapter 6 . The UK - and to a lesser extent Dutch - courts have found a way around the difficulties presented by factual determinations of the ECJ by concluding that they are not bound by an ECJ ruling on the facts. The UK courts have also been more upfront in challenging the ECJ through a second reference, although the

\footnotetext{
99 Case C-466/00 Kaba EU:C:2003:127; Case C-356/98 Kaba EU:C:2000:200, paras 29 and $57-58$.

100 Case C-169/91 Council of the City of Stroke-on-Trent EU:C:1992:519; Micklitz 2005.

101 Case C-145/88 Torfaen BC v B and Q plc EU:C:1989:693, para 17.

102 Case C-293/12 Digital Rights Ireland EU:C:2014:238; Privacy International $v$ The Secretary of State for Foreign and Commonwealth Affairs [2018] UKIP Trib IPT $15110 \mathrm{CH}$, paras 102-03 and 111.

103 Case C-623/17 Privacy International EU:C:2020:790.
} 
number of such references should not be exaggerated. The relatively straightforward follow-up thus camouflages the dissatisfaction of some courts with their interaction with the ECJ and with the quality of some ECJ judgments. 